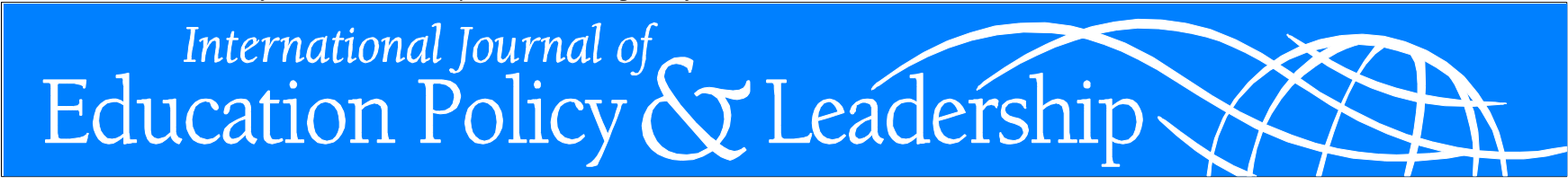

\title{
Perspectives About Living on the Horns of Dilemmas: An AnAlysis OF GENDER FACTORS RELATED TO SUPERINTENDENT DECISION-MAKING AND PROBLEM-SOLVING
}

\author{
WALTER S. POLKA \\ Niagara University \\ PETER R. LITCHKA \\ Loyola University \\ FRANK F. CALZI \\ Niagara University \\ STEPHEN J. DENIG ${ }^{1}$ \\ Niagara University \\ RosinA E. METE \\ Niagara University
}

\begin{abstract}
The major focus of this paper is a gender-based analysis of school superintendent decision-making and problem-solving as well as an investigation of contemporary leadership dilemmas. The findings are based on responses from 258 superintendents of K-12 school districts in Delaware, Maryland, New Jersey, New York, and Pennsylvania collected over a period of three years (2009-2011). The researchers also conducted 18 comprehensive qualitative "face-to-face" interviews with self-selected superintendents who responded to the quantitative survey. The intended outcome of this article is for education policy makers, professors, and practitioners to comprehensively examine the extent and degree of various dilemmas confronting the Mid-Atlantic Region school superintendent sample and to evaluate the decision-making and problem-solving approaches used by them. The study results that are presented will serve as valuable references to not only individual superintendents but also to university administrator preparation professors and to state administrator licensure agencies because it is important for all aspiring superintendents to know the various issues associated with education leadership and the personal and professional dilemmas that they need to be prepared to face as they embark on a career to improve schooling in the United States.
\end{abstract}

Polka, W. S., Litchka, P R., Calzi, F. F, Denig, S. J., \& Mete, R. E. (2014). Perspectives About Living on the Horns of Dilemmas: An Analysis of Gender Factors Related to Superintendent Decision-making and Problem-solving. International Journal of Education Policy E Leadership 9(1). Retrieved from www.ijepl.org.

${ }^{1}$ Stephen Denig passed away on May 22, 2013 but is listed here as appropriate to his contributions to this manuscript.

\section{Introduction}

This article is based on the findings of a mixedmethods research study conducted from 2009 to 2012 with school superintendents in the following five mid-Atlantic states: Delaware, Maryland, New Jersey, New York, and Pennsylvania. The major focus of this paper is a gender-based analysis of school superintendent decision-making and problem-solving processes and an investigation of their respective leadership dilemmas. To explore this topic, we sent 875 survey instruments to superintendents of $\mathrm{K}-12$ school districts in the five aforementioned states, and $258(\mathrm{~N}=258)$ useable survey instruments, or 29.6 percent of those distributed, were returned. In addition, 100 superin- 
tendents, or 38.8 percent of those who returned the survey, indicated their willingness to participate in the qualitative "face-to-face" interviews. We conducted 18 qualitative interviews with those self-selected superintendents. Our surveys and interviews demonstrate that practicing superintendents desire opportunities to reflect about their decision-making and problem-solving experiences and tell their stories about "living on the horns of dilemmas" as they lead school districts. The findings about the decision-making and problem-solving approaches used by female and male superintendents and their perspectives regarding the frequency and stressful impacts of school leadership dilemmas are presented to further expand the contemporary educational leadership knowledge base.

\section{The Survey Instrument}

The survey instrument that we developed consists of the following four parts: Part A, Demographic Data; Part B, Decision-Making/Problem-Solving Approaches; Part C, Personal and Professional Dilemmas; and Part D, Opportunity to Reflect About Top Three or More Dilemmas

Part A contains demographic data: (1) gender, (2) years of total educational experience, (3) years of administrative experience, (4) years in current position, (5) number of superintendencies held (including this one), (6) school district setting, (7) school district student population, (8) number of administrators in the district, (9) number of schools in the district, and (10) number of schools currently on the No Child Left Behind (NCLB) "needs improvement" list.

Part B of the survey instrument, Decision-Making/Problem-Solving Approaches, consists of 35 statements based on the research of Hoy and Tarter (2008). Part B is designed to assess the frequency of seven decision-making and problem-solving approaches used by educational leaders: classical, incremental, garbage can, shared decision making, satisficing, mixed scanning, and political.

This research study utilized categories identified by Hoy and Tarter (2008), who cogently describe each decision-making and problem-solving approach as follows:

- Classical approach is the rational systematic means-ends analysis focused on optimizing organizational goals.
- Incremental approach is the successive search for reasonable alternatives to facilitate good decision-making.

- Garbage Can approach consists of scanning and using previously identified solutions to solve problems.

- Shared Decision-making approach empowers others to assist in finding solutions to problems meaningful to them.

- Satisficing approach consists of making decisions that are acceptable to most of those impacted.

- Mixed Scanning approach involves broad ends and tentative means that focus on adapting decisions to policy guidelines.

- Political approach employs objectives that emerge spontaneously but are personally driven by the leader's need for power (Hoy and Tarter, 2008, p. 85).

Participants were requested to identify the frequency of their experiences with five statements from each of the above seven categories according to the 10-point Likert-type scale shown in Figure 1 .

The reliability of the 35 questions of Part B (Problem-Solving and Decision-Making Survey) is .816 according to Cronbach's alpha measurement. Thus, Part B of the instrument has construct validity based on the research of Hoy and Miskel (2008) and reliability in relationship to the decision-making and problem-solving approaches of contemporary superintendents.

Part C, Personal and Professional Dilemmas (Calzi-Polka Dilemma Survey), of this instrument measures the frequency with which current superintendents confront various dilemmas associated with school district leadership. Twelve prominent dilemmas, deduced from leadership literature and research, were articulated in the survey using a descriptive questioning technique. The construct validity of this part of the instrument was comprehensively articulated in a 2011 leadership publication (Polka, Litchka, Calzi, Denig, \& Mete, 2011). Figure 2 (next page) provides the brief descriptive survey questions addressing the 12 different dilemmas facing contemporary school leaders with selected construct validity references.

Thus, the Calzi-Polka Dilemma Survey (Part C) of this research instrument asks respondents to reflect about the frequency of their experiences

Figure 1. Likert Scale to Quantify Frequency of Use of Decision-Making and Problem-Solving Approaches

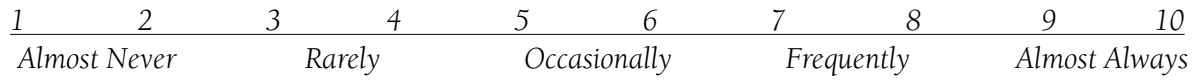




\section{Figure 2. Twelve Dilemmas with Construct Validity References}

Dilemma and Descriptive Question

Centralized versus decentralized decision making: Is it better to centralize and ultimately control the decision-making process rather than to decentralize and empower others to assume responsibility?

Personal life versus professional life: Is the personal cost too high in terms of the dilemma of dealing with one's own family issues while trying to meet the time and stress demands of leadership?

Truth versus varnished truth: Is it sometimes better and more humane to tell a half-truth rather than the whole truth to protect faculty interests and school building leadership and the school district one represents?

Creativity versus discipline of thought: Is it possible to provide greater latitude of freedom for some school building leaders and still maintain structure for others who need it within a climate of collegiality?

Trust versus change: Does implementing even the smallest of changes result in suspicion of your motives as a leader?

Leadership versus management: Is it critical to understand the difference between leadership and management and be able to put into practice one or the other when necessary?

Long-term goals versus short-term results: Is it critical for leadership job security to focus on short-term improvements in areas like student achievement test scores rather than implementing comprehensive quality student-centered programs?

Motivation versus manipulation: As an educational leader, are you authentically motivating your teams to accomplish goals rather than manipulating people to get the results you deem most appropriate for your own survival?

Independence versus dependence: Do you readily and too often accept the role of problem solver and decision maker rather than facilitate others to solve their own problems so as to foster less dependence on you as the key decider?

Conflict versus consensus: Is it best for the educational leader to promote consensus decision making on the part of teams rather than create dynamic tension that results in conflict but more meaningful problem resolutions?

Commitment versus compliance: Is it possible to achieve commitment during times of change that foster compliance given the bureaucratic nature and hierarchical chain of command of contemporary school systems?

Problems versus predicaments: Is the public we serve able to understand that several contemporary educational problems are really systemic predicaments that are more universal in nature than easily solved at the local level?

\section{References}

Bolman and Deal (1991); Friedman (2005); Klimek, Ritzenhein, and Sullivan (2008); and Reavis and Polka (2006)

Cashman (2008); Goleman (2002); Houston and Sokolow (2006); Litchka, Fenzel, and Polka (2009); Polka and Litchka (2008); and Polka, Litchka, and Davis (2008)

Collins (2001), DePree (1989), Kotter and Cohen (2002), Maxwell (2003), and Nyberg (1992)

Bennis (1989), Dlott (2007), Fullan (2008), and Kouzes and Posner (1987)

Cooper and Sawaf (1997), Duck (2001), Fullan (2008), and Polka and Litchka (2008)

Greenleaf (1977), Hersey and Blanchard (1988), Marzano (2003), Senge (1990), and Calzi (1974)

Blanchard and Waghorn (1997); Collins (2001); Kaufman, Herman, and Watters (2002); and Klimek et al. (2008)

Chance (2009), Fullan (2008), Greene (1998), Krass (1998), McGregor (1966), and Maslow (1970)

Hall and Hord (2006), Hoy and Tarter (2008), Tichy and Bennis (2007), and Reavis and Polka (2006)

Bennis (1989), Goleman (2002), Hall and Hord (2006), and Morgan (1997)

Duffy (2006), Hall and Hord (2006), Norton (2005), Tichy and Bennis (2007), and Polka and Litchka (2008)

Duffy (2006), Hoy and Miskel (2008), Norton (2005), Ravitch (2010), and Schlechty (2001) 
Figure 3. Gender and School District Settings of the Sample Population

\begin{tabular}{lccccc}
\hline \multicolumn{1}{c}{ Demographics } & \multicolumn{2}{c}{ Female } & & \multicolumn{2}{c}{ Male } \\
\cline { 2 - 3 } \cline { 5 - 6 } & Total & Percent & & Total & Percent \\
\hline Gender & 93 & 36 & & 165 & 64 \\
$\begin{array}{l}\text { Rural school dis- } \\
\text { trict }\end{array}$ & 46 & 77.4 & & 79 & 47.9 \\
$\begin{array}{l}\text { Suburban school } \\
\text { district }\end{array}$ & 44 & 47.3 & & 74 & 44.8 \\
$\begin{array}{l}\text { Urban school } \\
\text { district }\end{array}$ & 3 & 3.2 & & 12 & 7.3 \\
\hline
\end{tabular}

Figure 4. Number of Superintendencies Held Among Female and Male Superintendents

\begin{tabular}{lcccccc}
\hline \multirow{2}{*}{$\begin{array}{c}\text { Number of } \\
\text { Superinten- } \\
\text { dencies }\end{array}$} & \multicolumn{2}{c}{ Females } & & \multicolumn{2}{c}{ Males } \\
\cline { 2 - 3 } \cline { 5 - 6 } \cline { 5 - 6 } & Total & Percent & & Total & Percent \\
2 & 72 & 77.4 & & 96 & 58.2 \\
3 & 14 & 15.1 & & 41 & 24.8 \\
4 & 5 & 5.4 & & 14 & 8.5 \\
5 & 1 & 1.1 & & 4 & 2.4 \\
6 & - & - & & 5 & 3 \\
Totals & 93 & 100 & & 165 & 100 \\
\hline
\end{tabular}

Figure 5. Total Number of School Administrators in District Including Superintendent of Schools

\begin{tabular}{lccccc}
\hline \multirow{2}{*}{$\begin{array}{c}\text { Number of } \\
\text { Administrators }\end{array}$} & \multicolumn{2}{c}{ Females } & & \multicolumn{2}{c}{ Males } \\
\cline { 2 - 3 } \cline { 5 - 6 } & Total & Percent & & Total & Percent \\
\hline 10 or fewer & 49 & 53.3 & & 78 & 49.4 \\
$11-25$ & 32 & 34.8 & & 51 & 32.3 \\
$26-50$ & 10 & 10.9 & & 19 & 12.1 \\
$51-100$ & 1 & 1.1 & & 10 & 6.3 \\
Totals & 92 & 100 & & 158 & 100 \\
\hline
\end{tabular}

confronting each of the 12 identified leadership dilemmas constructed from the historic leadership literature and research. In addition, the same 10point Likert-type scale used in Part B of the instrument is employed in Part C.

Part D of the survey instrument, Opportunity to Reflect About Top Three or More Dilemmas, asks the superintendents to reflect and comment about three or more dilemmas that caused them the most stress as a superintendent of schools and provide advice to aspiring and current superintendents. Therefore, the survey instrument of this study is a comprehensive research tool designed to provide acute insight about the contemporary U.S. school superintendency and "living on the horns of dilemmas" (Polka et al., 2011).

\section{Demographics of Study Sample}

The quantitative sample for this research study was fairly representative of the general population of school superintendents in the mid-Atlantic region of the United States (Pennsylvania School Board Association, 2010, p. 35). The proportion of females to males was slightly higher, but the experience factors were similar in terms of their total years of educational experiences and administrative experiences, number of years in their current position, and number of superintendencies held during their careers. Their school district demographics were similar to other national trends in that the typical school district was more rural and/ or suburban than urban with student populations of fewer than 3,000 students and consisted of a limited number of schools and few other administrators (Glass \& Franceschini, 2007). The superintendent is, thus, the key decision maker and problem solver, with limited assistance provided by other administrators. Figures 3 and 4 provide key demographics of this study's sample.

Subsequently, more of the female superintendents (77.4 percent) reported that they were classified as superintendents of rural school districts, whereas 47.9 percent of the males so reported. Suburban superintendencies were somewhat equally divided between both males and females. However, the urban superintendents of this study were predominately male. The female superintendents of this mid-Atlantic sample generally held fewer different superintendencies than their male counterparts. Accordingly, 77.4 percent of the female superintendents reported that they were in 
Figure 6. Educational Experience, Administrative Experience, and Years in Current Position for Female Superintendents

\begin{tabular}{|c|c|c|c|c|c|c|}
\hline \multirow{2}{*}{$\begin{array}{l}\text { Years of } \\
\text { Experi- } \\
\text { ence }\end{array}$} & \multicolumn{2}{|c|}{$\begin{array}{l}\text { Educational } \\
\text { Experience }\end{array}$} & \multicolumn{2}{|c|}{$\begin{array}{l}\text { Administrative } \\
\text { Experience }\end{array}$} & \multicolumn{2}{|c|}{$\begin{array}{l}\text { Current } \\
\text { Position }\end{array}$} \\
\hline & Total & Percent & Total & Percent & Total & Percent \\
\hline $1-3$ & - & - & - & - & 46 & 49.5 \\
\hline $4-10$ & - & - & 23 & 24.7 & 40 & 43.0 \\
\hline $11-17$ & 6 & 6.5 & 22 & 23.7 & 7 & 7.5 \\
\hline $18-24$ & 14 & 15.1 & 27 & 29.0 & - & - \\
\hline 25-31 & 30 & 32.3 & 21 & 22.6 & - & - \\
\hline $32+$ & 43 & 46.2 & - & - & - & - \\
\hline Totals & 93 & 100 & 93 & 100 & 93 & 100 \\
\hline
\end{tabular}

Figure 7. Educational Experience, Administrative Experience, and Years in Current Position for Male Superintendents

\begin{tabular}{|c|c|c|c|c|c|c|}
\hline \multirow[t]{2}{*}{$\begin{array}{c}\text { Years of } \\
\text { Experience }\end{array}$} & \multicolumn{2}{|c|}{$\begin{array}{l}\text { Educational } \\
\text { Experience }\end{array}$} & \multicolumn{2}{|c|}{$\begin{array}{l}\text { Administra- } \\
\text { tive Experi- } \\
\text { ence }\end{array}$} & \multicolumn{2}{|c|}{$\begin{array}{l}\text { Current } \\
\text { Position }\end{array}$} \\
\hline & Total & Percent & Total & Percent & Total & Percent \\
\hline $1-3$ & 1 & .6 & 2 & 1.2 & 74 & 44.8 \\
\hline $4-10$ & 4 & 2.4 & 20 & 12.1 & 69 & 41.8 \\
\hline $11-17$ & 8 & 4.9 & 38 & 23.0 & 20 & 12.1 \\
\hline $18-24$ & 25 & 15.2 & 39 & 23.6 & 2 & 1.2 \\
\hline $25-31$ & 25 & 15.2 & 41 & 24.8 & - & - \\
\hline $32+$ & 102 & 61.2 & 25 & 15.2 & - & - \\
\hline Totals & 165 & 100 & 165 & 100 & 165 & 100 \\
\hline
\end{tabular}

Figure 8. School District Student Population for Female and Male Superintendents

\begin{tabular}{lccccc}
\hline \multicolumn{1}{c}{ Number of } & \multicolumn{2}{c}{ Females } & & \multicolumn{2}{c}{ Males } \\
\cline { 2 - 3 } \cline { 5 - 6 } \cline { 5 - 6 } & Total & Percent & & Total & Percent \\
\hline 1,000 or fewer & 29 & 31.5 & & 40 & 24.2 \\
1,001-3,000 & 34 & 37.0 & & 58 & 35.2 \\
3,001-6,000 & 25 & 27.2 & & 40 & 24.2 \\
6,001-10,000 & 3 & 3.3 & & 14 & 8.5 \\
10,001-20,000 & 1 & 1.1 & & 9 & 5.5 \\
Over 20,000 & - & - & & 4 & 2.4 \\
Totals & 92 & 100 & & 165 & 100 \\
\hline
\end{tabular}

their first superintendency, whereas 58.2 percent of the male superintendents so reported. However, 41.7 percent of the males reported that they were in their second, third, or more superintendent position, whereas only 22.7 percent of the females reported having more than one superintendency during their career. Also, as illustrated in Figure 5 (previous page), half of both female and male superintendents of this sample served in school districts with 10 or fewer administrators including themselves.

Figures 6 and 7 depict the educational experience, administrative experience, and years in the current superintendency for both the female and male superintendents of this research study. As illustrated by the data in both Figures 6 and 7 , almost half (46.2 percent) of the females had 32 years or more of experience in education, whereas almost twothirds (61.2 percent) of the male superintendents had 32 years or more of educational experience. However, a higher percentage of females (32.3 percent) than males (15.2 percent) had 25-31 years of educational experience. The superintendents in this sample generally had several years of experience in education. In addition, both females and males had about equal years of administrative experience, but more females (24.7 percent) than males (13.3 percent) had less than 10 years of administrative experience, whereas more males (15.2 percent) than females ( 0 percent) reported having $32+$ years of administrative experience. These data reflect the historical trend related to females not having the same degree of access to the superintendency in the 20 th century that males have had (Polka et al., 2008), but that trend is changing in this century. In addition, most of the superintendents in this sample, both females (92.5 percent) and males (86.6 percent), have been in their current superintendencies for 10 years or less. Therefore, these superintendents are a very experienced group of educators 
Figure 9. Number of Schools in District for Female and Male Superintendents

\begin{tabular}{llllll}
\hline $\begin{array}{l}\text { Number of } \\
\text { Schools }\end{array}$ & \multicolumn{2}{l}{ Females } & & & \multicolumn{2}{l}{ Male } \\
\cline { 2 - 3 } \cline { 5 - 6 } & Total & Percent & & Total & Percent \\
\hline $1-3$ & 49 & 53.3 & & 73 & 44.7 \\
$4-10$ & 38 & 41.3 & & 63 & 38.7 \\
$11-17$ & 3 & 3.3 & & 19 & 11.7 \\
$18-24$ & 1 & 1.1 & & - & - \\
$25-31$ & - & - & & 4 & 2.5 \\
$32+$ & 1 & 1.1 & & 4 & 2.5 \\
Totals & 92 & 100 & & 163 & 100 \\
\hline
\end{tabular}

who generally are fairly well experienced in administration but have more limited experiences in the superintendency.

Figures 8 (previous page) and 9 provide data relating to the size of the sample superintendents' school districts as measured by student population and the number of schools in the district. Accordingly, most of the superintendents, 95.7 percent of the females and 83.6 percent of the males, lead districts with a student population of fewer than 6,000 students, and most of them, 94.6 percent of females and 83.4 percent of males, have 10 or fewer schools within their respective districts. However, 16.7 percent of males and only 5.5 percent of females lead school districts that have more than 10 schools. In addition, 16.4 percent of males and only 4.4 percent of females lead school districts with more than 6,000 students. Subsequently, males are more likely than females to be superintendents in larger urban and suburban school districts.

In addition, this demographic sample's segregated results relative to schools on the NCLB list are as follows: the majority of female superintendents (82.8 percent) did not have a school on the NCLB list; however, 13 percent of this population had one school on the NCLB list. Similarly, 77 percent of male superintendents had no schools on the NCLB list, whereas 12 percent of male superintendents had one on the list. According to the data collected, student performance on NCLB achievement assessments was more reflective of the school district context than the superintendent's gender.

\section{Analysis of the Problem-Solving and Deci- sion-Making Survey}

We applied Statistical Package for the Social Sciences (SPSS) statistical treatments to the Part B data of this survey instrument and identified various levels of significance and correlation between and among the data. Figure 10 reflects the results of those findings.

The mean scores in Figure 10 are the aggregate mean scores of the five items in each of the seven decision-making and problem-solving categories. The scores in Figure 10 are mean scores and standard deviations disaggregated by gender. A series of independent sample $t$ tests, with gender as the independent variable and the frequency of use of the decision-making and problem-solving ap-

\begin{tabular}{|c|c|c|c|c|c|c|c|}
\hline \multirow{2}{*}{$\begin{array}{l}\text { Rank } \\
\text { Order }\end{array}$} & \multirow[t]{2}{*}{ Category } & \multicolumn{2}{|l|}{ Total } & \multicolumn{2}{|c|}{ Female } & \multicolumn{2}{|l|}{ Male } \\
\hline & & $\begin{array}{l}\text { Mean } \\
\text { Score }\end{array}$ & $\begin{array}{l}\text { Standard } \\
\text { Deviation }\end{array}$ & $\begin{array}{l}\text { Mean } \\
\text { Score }\end{array}$ & $\begin{array}{l}\text { Standard } \\
\text { Deviation }\end{array}$ & $\begin{array}{l}\text { Mean } \\
\text { Score }\end{array}$ & $\begin{array}{l}\text { Standard } \\
\text { Deviation }\end{array}$ \\
\hline 1 & Incremental & 29.29 & 14.83 & 28.78 & 14.85 & 29.58 & 14.85 \\
\hline 2 & Classical & 29.27 & 14.95 & 28.26 & 15.06 & 29.81 & 14.89 \\
\hline 3 & $\begin{array}{l}\text { Shared deci- } \\
\text { sion making }\end{array}$ & 27.11 & 13.70 & 27.34 & 14.56 & 26.97 & 13.25 \\
\hline 4 & $\begin{array}{l}\text { Mixed scan- } \\
\text { ning }\end{array}$ & 26.49 & 12.77 & 26.72 & 13.33 & 26.35 & 12.48 \\
\hline 5 & Satisficing & 24.86 & 12.65 & 23.97 & 12.83 & 25.35 & 12.56 \\
\hline 6 & Garbage can & 23.37 & 12.91 & 23.47 & 13.52 & 23.31 & 12.6 \\
\hline 7 & Political & 21.75 & 11.16 & 21.51 & 11.78 & 21.88 & 10.83 \\
\hline
\end{tabular}


proach as the dependent variable, revealed no gender-related statistical differences.

\section{Analysis of the Dilemma Survey}

We also reviewed the data collected in Part $C$ in relationship to the 12 dilemmas derived from leadership literature and research. Figure 11 shows the gender-specific rank listing of the dilemmas and mean scores.

Therefore, both female and male mid-Atlantic school superintendents identified that the most frequent decision-making and problem-solving dilemma they faced related to the issue of leadership versus management $(m=8.34$ and $m=8.56$, respectively). Consequently, it is crucial for all superintendents to comprehend the difference between leadership and management and be able to utilize the most pertinent approach when neces- sary. According to our research, the rankings of the various dilemmas for female and male superintendents are different in the following ways:

Compared to the combined rank, commitment versus compliance was the fourth most frequent dilemma encountered by female superintendents, and conflict versus consensus was ranked fifth. Female superintendents had the dilemmas of longterm goals versus short-term results and centralized versus decentralized decision making tied as the eighth most frequently encountered dilemmas. In contrast, male superintendents ranked trust versus change and centralized versus decentralized at 9 and 10, respectively. Female superintendents placed the dilemma of trust versus change in the eleventh rank and problems versus predicaments in the tenth rank, which was the opposite of the combined rank scores.

The only dilemma that was significantly different between female and male superintendents was

Figure 11. Ranking of Dilemmas by Mean Score

\begin{tabular}{|c|c|c|c|c|c|c|c|}
\hline \multirow{2}{*}{$\begin{array}{l}\text { Combined } \\
\text { Rank }\end{array}$} & \multirow[t]{2}{*}{ Dilemma } & \multicolumn{2}{|l|}{ Total } & \multicolumn{2}{|c|}{ Female } & \multicolumn{2}{|l|}{ Male } \\
\hline & & $\begin{array}{l}\text { Mean } \\
\text { Score }\end{array}$ & $\begin{array}{l}\text { Standard } \\
\text { Deviation }\end{array}$ & $\begin{array}{l}\text { Mean } \\
\text { Score }\end{array}$ & $\begin{array}{l}\text { Standard } \\
\text { Deviation }\end{array}$ & $\begin{array}{l}\text { Mean } \\
\text { Score }\end{array}$ & $\begin{array}{l}\text { Standard } \\
\text { Deviation }\end{array}$ \\
\hline 1 & $\begin{array}{l}\text { Leadership versus manage- } \\
\text { ment }\end{array}$ & 8.48 & 1.445 & 8.34 & 1.424 & 8.56 & 1.462 \\
\hline 2 & $\begin{array}{l}\text { Motivation versus manipula- } \\
\text { tion }\end{array}$ & 7.68 & 2.158 & 8.14 & 1.621 & 7.47 & 2.331 \\
\hline 3 & $\begin{array}{l}\text { Creativity versus discipline } \\
\text { of thought }\end{array}$ & 7.24 & 1.600 & 7.15 & 1.696 & 7.28 & 1.557 \\
\hline 4 & Conflict versus consensus & 6.77 & 1.858 & 6.67 & 1.770 & 6.80 & 1.911 \\
\hline 5 & $\begin{array}{l}\text { Commitment versus compli- } \\
\text { ance }\end{array}$ & 6.70 & 1.465 & 6.86 & 1.632 & 6.61 & 1.365 \\
\hline 6 & $\begin{array}{l}\text { Personal life versus profes- } \\
\text { sional life }\end{array}$ & 5.79 & 1.974 & 5.57 & 2.040 & 5.93 & 1.927 \\
\hline 7 & $\begin{array}{l}\text { Independence versus depen- } \\
\text { dence }\end{array}$ & 5.53 & 1.790 & 5.54 & 1.712 & 5.54 & 1.837 \\
\hline 8 & $\begin{array}{l}\text { Long-term goals versus } \\
\text { short-term results }\end{array}$ & 5.11 & 1.878 & 4.95 & 2.040 & 5.21 & 1.781 \\
\hline 9 & $\begin{array}{l}\text { Centralized versus decentral- } \\
\text { ized decision making }\end{array}$ & 4.97 & 1.765 & 4.95 & 1.890 & 4.99 & 1.698 \\
\hline 10 & Trust versus change & 4.96 & 2.084 & 4.83 & 2.160 & 5.05 & 2.048 \\
\hline 11 & $\begin{array}{l}\text { Problems versus predica- } \\
\text { ments }\end{array}$ & 4.91 & 1.805 & 4.85 & 1.827 & 4.97 & 1.794 \\
\hline 12 & Truth versus varnished truth & 3.36 & 1.894 & 3.49 & 1.874 & 3.30 & 1.913 \\
\hline
\end{tabular}


the motivation versus manipulation dilemma. An independent samples $t$ test comparing genders found $t_{(255)}=2.46, p=.001$. Female superintendents in this sample encountered the dilemma more often than their male colleagues $(m=8.14$ and $m=7.47$ for female and male superintendents, respectively). This dilemma is the second-highestrecorded dilemma of the 12 dilemmas.

\section{Analysis of the Opportunity to Reflect}

In addition, we applied SPSS statistical treatments to the Part D data of this survey instrument and identified correlations among the data set in its entirety and disaggregated by gender. The results of these findings are identified in Figure 12, which provides a comparison between the ranking of dilemmas according to this sample's frequency of experience with them versus this sample's perspective of the degree of stress that each of those dilemmas caused them. It is interesting to note the gender differences in those rankings and their relevance to practicing superintendents, aspiring superintendents, and those who prepare them.

The results show that female superintendents of this sample may not rank their frequency of expe- riences with the personal versus professional dilemma very high but this dilemma has the most stressful impact upon them personally. In addition, problems versus predicaments is one of the least experienced dilemmas by female superintendents; however, it is the second-ranked dilemma for stressful impact. The dilemmas of trust versus change and leadership versus management are both ranked high for stressful impact; however, of the two, trust versus change is not encountered as frequently. The female respondents identified that although they confront the dilemmas of creativity versus discipline of thought, commitment versus compliance, and motivation versus manipulation frequently in their leadership roles, these dilemmas do not cause them as much personal stress as some of the other less frequently experienced dilemmas. These issues may not often be addressed in educational leadership programs but need to be because most superintendents deal with them, and they do cause leadership stress (Litchka et al., 2009). An interesting ranking is that of conflict versus consensus, which is ranked as less stressful in both the overall sample and the female superintendent sample but not among the male superintendents. Furthermore, upon examination of the qualitative

Figure 12. Ranking of Dilemmas According to Part C and Part D Responses

\begin{tabular}{|c|c|c|c|c|c|c|}
\hline \multirow[t]{2}{*}{ Dilemma } & \multicolumn{2}{|l|}{ Total } & \multicolumn{2}{|l|}{ Females } & \multicolumn{2}{|l|}{ Males } \\
\hline & $\begin{array}{l}\text { Part C } \\
\text { Ranking }\end{array}$ & $\begin{array}{l}\text { Part D } \\
\text { Ranking }\end{array}$ & $\begin{array}{l}\text { Part C } \\
\text { Ranking }\end{array}$ & $\begin{array}{l}\text { Part D } \\
\text { Ranking }\end{array}$ & $\begin{array}{l}\text { Part C } \\
\text { Ranking }\end{array}$ & $\begin{array}{l}\text { Part D } \\
\text { Ranking }\end{array}$ \\
\hline Centralized versus decentralized & 9 & 9 & 8 & 8 & 10 & 10 \\
\hline Personal life versus professional life & 6 & 1 & 6 & 1 & 6 & 4 \\
\hline Truth versus varnished truth & 12 & 7 & 11 & 7 & 12 & 7 \\
\hline Creativity versus discipline of thought & 3 & 11 & 3 & 11 & 3 & 11 \\
\hline Trust versus change & 10 & 3 & 10 & 3 & 9 & 2 \\
\hline Leadership versus management & 1 & 2 & 1 & 3 & 1 & 1 \\
\hline $\begin{array}{l}\text { Long-term goals versus short-term re- } \\
\text { sults }\end{array}$ & 8 & 5 & 8 & 5 & 8 & 7 \\
\hline Motivation versus manipulation & 2 & 8 & 2 & 8 & 2 & 6 \\
\hline Independence versus dependence & 7 & 6 & 7 & 6 & 7 & 9 \\
\hline Conflict versus consensus & 4 & 9 & 5 & 12 & 4 & 5 \\
\hline Commitment versus compliance & 5 & 12 & 4 & 10 & 5 & 12 \\
\hline Problems versus predicaments & 11 & 4 & 9 & 2 & 11 & 3 \\
\hline
\end{tabular}


responses to Part D for each of the 12 categories, there were no differences in the pattern of responses based on gender. Figure 13 identifies representa- tive personal comments regarding each of the 12 dilemmas from superintendents in this sample.

Figure 13. Selected Part D Sample Responses Organized by Gender

\begin{tabular}{lll}
\hline Dilemma & Females & Males \\
\hline Centralized versus & The district made decentralized deci- & While I appreciate local decision making, I \\
decentralized & sions and found it difficult to change to also need to be comfortable knowing that \\
decision-making & a consistent, centralized approach, the district "nonnegotiables" are being \\
& which I deemed necessary for im- honored. I often find myself saying, "That's \\
& provement. & great but don't forget to..." As I say that, I \\
& hope I am not minimizing great ideas.
\end{tabular}

Personal life versus professional life

Truth versus varnished truth

Creativity versus discipline of thought

Trust versus change
This is the only area where I treated myself differently from my coworkers and subordinates. I ask all of my employees to "put family first" because if they come to work worrying about a loved one at home, their head won't be in the right place on the job. When it came to myself, however, work always came first. I missed every major event in my own children's lives. I tell all my administrators to use Stephen Covey's concept of "sharpening the saw." Spend time with family. Take time to exercise and relax.

I would never promote untruth, but buying time by not providing the entire set of information protects the team while we work on improvement.

It becomes clear to a leader when leaders can handle any problem by bringing a solution and on the contrary when leaders cannot solve any problem without chaos.

There is resistance to change or reform practice at every level of the organization. It is most prominent in districts perceived as excellent because of their socioeconomic status.
The superintendent's personal life many times is public. Because of the expectations, board's, public, schools, etc., the personal obligations get set on the back burner. It is difficult for boards and community to understand and accept that the 24/7 concept is detrimental to the superintendent. I can recall birthdays, anniversaries, games, and events missed, yet with no acknowledgement by the board.

It may have at one time been more humane to hold back in order to spare someone. In this age of unbridled auditing and unparalleled public scrutiny, holding back falls under the umbrella of "no good deed will go unpunished."

It can be a fine line between encouraging creativity in building leadership and keeping those leaders focused on the district goals. I have learned that it works best if I encourage independence and creativity while at the same time demanding feedback on progress towards established goals. I also try to be open-minded about this.

This mostly involves relationships with certain board of education members. The most difficult job a superintendent has in my mind is with board relations and members who have hidden agendas and motives. 
Leadership versus management

Short-term goals versus long-term results

Motivation versus manipulation

Independence versus dependence

Conflict versus consensus

Commitment versus compliance
As superintendent, every minute of every day would be consumed with management issues. So every day I fight the urge to stay in my office and manage. As a result, my meetings are designed around a shared vision of leadership. I visit schools weekly to work with the leaders of the schools.

Board of education wants to see results fast, especially during the first year. Again, no one understands that change takes time. Therefore, a superintendent should focus on one or two short-term goals that can be accomplished successfully and then a few long-term goals. Educating the board and working with them is a key "stressor" for superintendents.

When you have a couple of older staff who have been in "control" of the building, you are constantly trying to second guess what they will do next. So many times, this consumes all of your energy.

I am frequently approached by staff and community members to solve problems for them. When I redirect them in ways to help them solve their own problem, I am judged as being nonsupportive.

Consensus decision making can lead to "I can live with it" mentality that is not most productive nor effective when it comes to implementation. A certain "tension" is healthy, as it results when people have shared divergent viewpoints, ideas, suggestions, etc. Many people are not comfortable with such tension and would readily opt for "getting along" over better solutions and decisions.

Commitment is necessary to affect long-term change, and many people have the "this too will pass" idea surrounding necessary changes.
I learned quickly and often that if I make a decision or say something that a constituent doesn't like, they often make it personal and attack my integrity. Leadership dictates that I carefully consider all angles, make the best decision for the district, and stand by it.

I am an educational leader who has visions and dreams that are more often long range. I often find myself in an internal conflict between those visions and the need to attend to more immediate and public matters such as achievement scores. It is often difficult to look 5-7 years ahead when you're looking over your shoulder.

Motivate versus manipulate is an interesting concept. Like a Herzberg scale, I don't see them as opposite. I see my charge as motivating people. If they judge it as manipulating, they are questioning my motivation. I ask them to judge my actions, which you can see, not my motives, which you cannot see.

Developing capacity in others is important because a superintendent can't do everything himself. But you still have the "problem" that you have to monitor what others are doing or find you have overdelegated.

To "create dynamic tension" is the ultimate balancing act. It eliminates stagnation, acknowledges a culture of change, and inspires new and exciting ideas without fear of results that are initially less than ideal.

A perfect example of this dilemma is with the requisite professional development plan. Faculty have needs/desires for professional growth that may not correlate exactly to student data-thus, often, their needs/desires are not attended to, leading to frustration and lack of commitment. 
Problems versus predicaments
The public does not understand the The public's understanding of educational complexities of school operations. The issues is generally limited to what they burden on the local tax payer in fund- read in the media or have heard through ing their local schools in the manner rumor. Because so much of what we do they want causes scrutiny about educa- affects taxes, the public usually looks at tors' salaries and benefits. School dis- what the impact is to them. A rational untricts are working with less administra- derstanding is many times overshadowed tors and overall support staff to keep by the visceral or emotional reaction. their local schools a productive and positive place for children to grow and learn.
In addition, the superintendents included their advice for educators who either are currently practicing superintendents or have career aspirations in leadership. Figure 14 outlines key personal re- sponses from both female and male superintendents that we determined were not significantly different based on gender.

Figure 14. Advice for Educators from Female and Male Superintendents

Female Responses
Remember: first and foremost, you are a
teacher and a mentor. You teach others
about the realities of leading and managing
a school, you mentor your administrators
and colleagues, and you must always be
there to teach board members about their
role.

Be ethical and do what's right.

Have in mind what is truly important to you so that decisions are made by moral compass.

Create and maintain resilience. Know who you are and what you value. Know and maintain your support system. Participate in activities that rejuvenate yourself. Be willing to apologize.

Organization, time management, and communication are keys to success.
Keep leadership simple. Be able to do the "heavy lifting," taking on rogue boards and community members. Use the educational conventions that have stood the test of time. Learn to laugh at ridiculous issues. A prime criterion for being a superintendent is the acceptance of its temporary nature. There is a need to be aware of and somewhat accepting of the eventual need to move on and relocate.

Be very clean in expressing your position and motives regarding issues. Follow your moral compass.

Remember it's not about you. Cultivate relationships especially with the board of education and staff. Be collaborative in your planning, and listen to others. Become a thought leader. Stress to admin and faculty that you model lifelong learning. Learn to communicate to all in the community-use technology as a tool. Be known as a leader who is known for something positive. Become one of the employees. Remember you are the highest-paid employee, but go easy on the bells and whistles. Make the board of education feel special. Every day, remember your own personal mission statement and the words of John Gardner: "The first and last job of a leader is to give people hope."

Balance, honesty, compassion, high expectations of people, and developing peer support. 


\section{Analysis of Qualitative Interviews}

The qualitative part of this mixed study of superintendent decision-making and problem-solving also consisted of interviews that we conducted. We interviewed 18 of the 100 superintendents who volunteered: 5 female and 13 male superintendents. The interviews reconfirmed the key issues related to making decisions and solving problems while "living on the horns of dilemmas." Figure 15 illustrates the representative personal responses of in- dividual superintendents from the sample population to questions that we posed. Superintendents are identified by gender-specific names in alphabetical order, starting with Anne and ending with Keith, in the appropriate gender columns. The names are fictional to maintain confidentiality.

Figure 15 shows that this sample's participants identified that the superintendency is challenging, time consuming, and stressful to one's physical and emotional health and family relationships.

\section{Figure 15. Representative Superintendent Responses to Interview Questions Disaggregated by Gender}

\begin{tabular}{lll}
\hline Question & $N($ Females $)=4 / 5$ & $N($ Males $)=7 / 13$
\end{tabular}

What were the situa- Superintendent Anne: The greatest tions that led to dilemma was a lack of trust when change dilemmas during was needed. There was a need for authoryour superintenden- itarian leadership to get the board from cy?

micromanaging.

Superintendent Bernice: Personal life versus professional life. I was asked, "If you live 50 miles from where you work, how can you address the issues of the district?" and questioned my decision not to live in the district. Truth is sometimes varnished to protect the district image.

Superintendent Catherine: Management versus leadership-managing a board that expects updates on every situation or issue. Independence versus dependence-problem with a principal who had difficulty making his own decisions or recommendations, always sought my input.

Superintendent Debra: Creativity versus discipline of thought. Lack of performance by a principal who could not make up his mind. Personal versus professional life. Change in expectations of the board regarding my responsibilities for a capital project that was overwhelming.
Superintendent Edward: Person elected to the board came on to attack me. Trust was an issue. Personal attack to destroy my career.

Superintendent Fred: Mandates of the state have been huge. Single biggest problem: we do not recognize the importance of a quality public education program.

Superintendent George: Trust versus change is a huge issue particularly in today's financial climate. Administrators have taken a pay freeze.

Superintendent Jim: Truth versus varnished truth. Need to protect the integrity of the budget process particularly during negotiations and when large-scale layoffs occur.

Superintendent Keith: Real disconnect with the public's perception of education and what is happening in their local school district. Everyone appears to support their local school district but have a less than favorable impression of public education. 
What were your immediate and longterm reactions to these dilemmas?
Superintendent Bernice: I am not entitled to my position. It is not an entitlement.

Superintendent Catherine: Tried various interventions to assist a principal in his decision making, but to no avail, needed to counsel him to leave the district. Superintendent Debra: Reassigned recalcitrant principal to another position for a year until he resigned.
Superintendent Fred: People have to work together. I use Marzano's framework for instructional purposes-use the word "commitment" instead of "values." Superintendent Ivan: I established good relationships with the union. I was able to secure changes in the contract to save teacher positions. Responsibility to give back to the profession.

Superintendent Keith: Centralized versus decentralization. It is all about responsibility. You can delegate, but you cannot delegate responsibility. When you empower others, be sure they have the right skills to do the job.

What were the effects these dilemmas/crises had on your family and friends?

What skills did you use to try and overcome the dilemmas?
Superintendent Anne: I did not take issues home-it would be regurgitating all over again. Supportive family.

Superintendent Bernice: I am able to separate the daily challenges of the job, and I do not dwell on the issues at home. My husband has been an excellent sounding board.

Superintendent Catherine: In the beginning of my superintendency my husband (corporate manager) and I both took home issues we faced in our daily responsibilities. Now such issues are rarely discussed, and by doing so, our home life has become much better!

Superintendent Debra: Initially, I took some "heat" from the community for my decision to "warehouse" the principal, but it was eventually accepted as the "best option" because of board support.

Superintendent Anne: Always when communicating with the press, put the district in the most favorable light. In the beginning it was my way or the highway. Be honest.

Superintendent Bernice: Use humor whenever possible.

Superintendent Catherine: Constantly find myself assessing my actions on serious issues. More reflective now than in the beginning.

Superintendent Debra: Needed to accept the demands of the position as being 24/7 and then learned to deal with that!
Superintendent Edward: I was a bear to live with-my temper was short. My children understood the issue, but my spouse tried to shield them.

Superintendent Fred: I am competitiveimmersed in what I am doing. I try not to take the job home but do continue to think about it.

Superintendent George: With the growth of technology I was available 24/7 (texting, laptop). Because I pursued the superintendency, my wife had to give up her career. My son had a difficult timehad to go to a private school.

Superintendent Jim: Personal life not affected. Able to share war stories. Do not discuss school issues on weekends.

Superintendent Fred: I kept students my focus-what was best for them. I tried not to become a part of a personal agenda. I felt there was nothing I could do because of no trust.

Superintendent George: I created vision and followed through on that vision. I used a collaborative style.

Superintendent Harold: I was able to build relationships. Strong beliefs of what public school is all about.

Superintendent Keith: Being a good listener. Ask, don't answer. The job is not about always having the right answers but being able to ask the right questions. 
What advice would Superintendent Anne: It is critical to you give to current know when your leadership style is no and aspiring superin- longer effective. Be honest and transpartendents who are ent. faced with similar Superintendent Bernice: Be involved in dilemmas?

as many important issues facing the district. Do not be in such a hurry to move up the ladder.

Superintendent Catherine: Be transparent. Be clear in your thinking. Encourage your staff (both administrators and teachers) to be independent and assume a leadership role in decision making.

Superintendent Debra: Seek a respected mentor. Do your homework about the district before accepting a superintendency. Note the expectations that the community has of its school leader on terms of time and energy.
Superintendent Fred: Do not get caught up in the single-issue candidate demands. Be proactive not reactive. Issues are the same for all superintendents regardless of the district.

Superintendent George: Relationships are key to success. Five for five: every time you go into a building spend five minutes each with five people.

Superintendent Harold: Go into the position with your eyes open-you are not going to change things overnight.

Superintendent Jim: Learn to pace yourself-some problems cannot be solved overnight. Take care of yourself personally.

Superintendent Keith: Seek a mentor early on in your career.

\section{Summary, Conclusions, and Recommenda- tions}

The superintendents in this sample provided acute insight into their decision-making and problemsolving approaches and the dilemmas they confront. This sample reinforced the significance of the Hoy and Tarter (2008) decision-making and problem-solving model in that the incremental and classical approaches are most frequently used. However, the superintendents also identified that the shared decision-making model and mixed scanning model are frequently used by them. The superintendents also identified that the satisficing approach, the garbage can approach, and the political approach are employed but not as frequently as the incremental, classical, shared decision-making, and mixed scanning approaches. Thus, it is important that aspiring superintendents as well as those currently holding superintendencies review the various aspects and impacts of the seven decision-making and problem-solving approaches articulated by Hoy and Tarter (2008) and researched in this study because they most likely will employ all of them to some extent in their leadership careers.

However, based on the findings of this study, we conclude that there were no significant differences in the Hoy and Tarter (2008) approaches used based on the gender of the superintendent. However, an analysis of the findings concludes that superintendents in small school districts in rural ar- eas with few other administrators employ all of the decision-making and problem-solving approaches more frequently than other superintendents. It may be speculated that context of the school district may have more influence than the gender of the superintendent on the decision-making approaches employed. Therefore, we determined that there is more to be studied about the decisionmaking and problem-solving approaches used by female superintendents in rural and urban settings to determine the relationship between context and gender on their preferences.

The superintendents also confirmed that they often faced the 12 dilemmas identified in this study. However, the frequency of facing those dilemmas differed by gender, but the only significant difference based on gender was in terms of the motivation versus manipulation dilemma. Perhaps this is a manifestation of the perceptions of female superintendents within such a competitive work force. This may be a residual aspect of the "glass ceiling" syndrome. Female superintendents faced this dilemma significantly more than did their male counterparts. However, the ranking of the stress level of the dilemmas was similar for females and males, with no significant differences found. In addition, the findings indicate that the context of the school district is a key factor in the frequency of dilemmas facing superintendents. Therefore, superintendents and those aspiring to positions in leadership need to be cognizant of these dilemmas and prepare to personally and professionally ad- 
dress them, especially given the context of their school districts.

Thus, the decision-making and problem-solving approaches used by superintendents and the dilemmas they face were specifically reviewed and analyzed via this study. This information is presented to facilitate the effective preparation and professional development of superintendents of schools so that they may comprehend the potential obstacles relating to contemporary leadership and learn to "live and thrive on the horns of dilemmas."

\section{References}

Bennis, W. (1989). On becoming a leader. Reading, MA: Addison-Wesley.

Blanchard, K., \& Waghorn, T. (1997). Mission possible: Becoming a world-class organization while there's still time. New York: McGraw-Hill.

Bolman, L., \& Deal, T. (1991). Reframing organizations. San Francisco, CA: Jossey-Bass.

Calzi, F. (1974). Analysis of the current status of management by objectives and the development of a management by objectives model for use in school districts. Buffalo, NY: State University of New York at Buffalo.

Cashman, K. (2008). Leadership from the inside out: Becoming a leader for life (2nd ed.). San Francisco, CA: Barrette-Koehler.

Chance, P. (2009). Introduction to educational leadership and organizational behavior: Theory into practice. Larchmont, NY: Eye on Education.

Collins, J. (2001). Good to great. New York: HarperCollins.

Cooper, R., \& Sawaf, A. (1997). Executive e q: Emotional intelligence in leadership and organizations. New York: Berkley Press.

DePree, M. (1989). Leadership is an art. New York: Dell.

Dlott, S. (2007). Surviving and thriving as a superintendent of schools. Lanham, MD: Rowman and Littlefield.

Duck, J. (2001). Change monster. New York: Crown Press.

Duffy, F. (2006). Power, politics, and ethics in school districts. Lanham, MD: Rowman and Littlefield.

Friedman, T. (2005). The world is flat. New York: Farrar, Straus and Giroux.

Fullan, M. (2008). The six secrets of change. San Francisco, CA: Jossey-Bass.
Glass, T., \& Franceschini, L. (2007). The state of the American superintendency: A mid-decade study. Lanham, MD: Rowman and Littlefield.

Goleman, D. (2002). Primal leadership. Boston, MA: Harvard Business School Press.

Greene, R. (1998). The 48 laws of power. New York: Penguin.

Greenleaf, R. (1977). Servant leadership. Mahwah, NJ: Paulist Press.

Hall, G., \& Hord, S. (2006). Implementing change: Patterns, principles, and potholes (2nd ed.). Boston, MA: Pearson Education.

Hersey, P., \& Blanchard, P. (1988). Management of organizational behavior. Englewood Cliffs, NJ: Prentice Hall.

Houston, P., \& Sokolow, S. (2006). The spiritual dimension of leadership. Thousand Oaks, CA: Corwin Press.

Hoy, W., \& Miskel, C. (2008). Educational administration: Theory, research, and practice. Berkshire, UK: McGraw-Hill.

Hoy, W., \& Tarter, J. (2008). Administrators solving the problems of practice: Decision-making concepts, cases, and consequences (3rd ed.). Boston, MA: Pearson.

Kaufman, R., Herman, J., \& Watters, K. (2002). Educational planning: Strategic, tactical and operational. Lanham, MD: The Scarecrow Press.

Klimek, K., Ritzenhein, E., \& Sullivan, K. (2008). Generative leadership. Thousand Oaks, CA: Corwin Press.

Kotter, J., \& Cohen, D. (2002). The heart of change: Real life stories of how people change their organizations. Boston, MA: Harvard Business School Press

Kouzes, J., \& Posner, B. (1987). The leadership challenge. San Francisco, CA: Jossey-Bass.

Krass, P. (1998). The book of leadership wisdom. New York: John Wiley.

Litchka, P., Fenzel, M., \& Polka, W. (2009). The stress process among school superintendents. International Journal of Educational Leadership Preparation, 4(4), 1-7.

Marzano, R. (2003). What works in schools: Translating research into action. Alexandria, VA: ASCD.

Maslow, A. (1970). Motivation and personality. New York: Harper and Row.

Maxwell, J. (2003). Ethics 101. New York: Center Street.

McGregor, D. (1966). Leadership and motivation. Cambridge, MA: MIT Press. 
Morgan, G. (1997). Images of organization. Thousand Oaks, CA: Sage.

Norton, M. (2005). Executive leadership for effective administration. Boston, MA: Pearson.

Nyberg, D. (1992). The varnished truth: Truth telling and deceiving in ordinary life. Chicago, IL: University of Chicago Press.

Pennsylvania School Board Association (2010). Superintendent directories and demographics. Retrieved from http://www.psba.org/issues-advocacy/issues-research/schools-schoolboards/ school-director-profile-2010.pdf

Polka, W., \& Litchka, P. (2008). The dark side of educational leadership: Superintendents and the professional victim syndrome. New York: Rowman and Littlefield.

Polka, W., Litchka, P., \& Davis, S. (2008). Female superintendents and the professional victim syndrome: Preparing current and aspiring superintendents to cope and succeed. Journal of Women in Educational Administration, 6(4), 293-311.

Polka, W., Litchka, P., Calzi, F., Denig, S., \& Mete, R. (2011). Living on the horns of dilemmas: A quantitative study of superintendent decisionmaking and problem-solving. In B. Alford et al. (Eds.), Blazing new trails: Preparing leaders for improving access and equity in today's schools. The 2011 Yearbook of the National Council of Professors of Educational Administration (pp. 93108). Lancaster, PA: DEStech.
Ravitch, D. (2010). The death and life of the American school system: How testing and choice are undermining education. New York: Basic Books.

Reavis, C., \& Polka, W. (2006). A tale of two districts: Planning for the professional development of school leaders to improve student achievement. Educational Planning, 15(2), 1324.

Schlechty, P. (2001). Shaking up the schoolhouse. San Francisco, CA: Jossey-Bass.

Senge, P. (1990). The fifth discipline: The art and practice of the learning organization. New York: Doubleday.

Tichy, N., \& Bennis, W. (2007). Judgment: How winning leaders make great calls. New York: Penguin.

IJEPL is a joint publication of PDK International, the Faculty of Education at Simon Fraser University and the College of Education and Human Development at George Mason University. By virtue of their appearance in this open access journal, articles are free to use, with proper attribution, in educational and other non-commercial settings 90 days after initial publication. Copyright for articles published in IJEPL is retained by the authors. More information is available on the IJEPL Web site: http://www.ijepl.org 